\title{
CONSTITUTIONAL LEGAL DISPUTES BETWEEN THE PRESIDENT OF ROMANIA AND OTHER PUBLIC AUTHORITIES IN THE CASE-LAW OF THE CONSTITUTIONAL COURT OF ROMANIA
}

\section{Mihaela SIMION}

\section{SIMION}

University "1 Decembrie 1918" Alba Iulia, Romania

*Correspondence: Mihaela Simion, 15-17 Strada Unirii, Alba Iulia, Romania

E-mail: simionmihaela10@gmail.com

\begin{abstract}
Article 146 (e) of the Romanian Constitution stipulates the power of the Constitutional Court to solve legal disputes of a constitutional nature between public authorities. Thus, the Constitutional Court solves or settles constitutional disputes between the authorities belonging to the three powers in the state. These situations may concern disputes between two or more constitutional authorities regarding the content or length of their powers, as provided for by the Constitution. The result sought is to overcome possible institutional blockages.

From 2005, when the Constitutional Court of Romania first decided on such dispute, and until today, thirteen decisions for settling certain disputes between the President of Romania and other public authorities have been issued. The multitude of disputes is due, primarily, to the semi-presidential system of government provided for by the Constitution and to the ambiguous provisions regarding the division of powers between the Romanian President, Government, Parliament and the judicial power. Last but not least, this dispute is due to a certain political context, too.

The present paper aims to analyze the case-law of the Constitutional Court of Romania regarding the constitutional legal disputes between the President of Romania and other public authorities, as well as its impact on the constitutional order and the relationships between the public authorities from the checks and balances system.
\end{abstract}

KEYWORDS: Constitution, Constitutional Court, constitutional legal disputes, public authorities, President of Romania.

\section{INTRODUCTION}

The emergence of certain conflicts between public authorities is quite natural given the fact that these authorities are organized and operate on the principle of separation and balance of powers, a principle that involves, when talking about collaboration, areas of autonomy and independence ${ }^{1}$.

Following the model of constitutions of Austria, Poland and Slovakia, since 2003, the Constitution of Romania, through Article 146 (e), assigns to the Romanian Constitutional Court the competence to settle legal disputes of a constitutional nature between public authorities, at the request of the President of Romania, one of the presidents of the two Chambers, the Prime Minister or the President of the Superior Council of Magistracy. It is, therefore, a political prerogative exercised exclusively by the Romanian constitutional contentious court, in its capacity as guarantor of the supremacy of the Constitution.

\footnotetext{
${ }^{1}$ Ioan Muraru, Elena Simina Tănăsescu, Constituția României. Comentariupearticole, CH Beck Publishing House, Bucharest, 2008, pp. 1404-1405.
} 


\section{THE CONCEPT OF CONSTITUTIONAL LEGAL CONFLICTS BETWEEN PUBLIC AUTHORITIES}

Disputes that may concern conflicts between two or more constitutional authorities on the content or scope of their duties arising from the Constitution represent the object of situations stipulated by Article 146 (e) of the Constitution. Therefore, the Constitutional Court will settle positive or negative conflicts of competence between two public authorities that declare interest or invoke their incompetence in solving the same problem. In the case of positive conflict of competence, two or more public authorities declare their jurisdiction to regulate or to solve one and the same problem. Instead, there will be a negative conflict of competence where two or more public authorities decline jurisdiction or refuse to perform certain acts that fall within their obligations. The net effect of conflicts of competence between public authorities is the emergence of institutional blockages between them.

In the attempt to define as precisely as possible the term "constitutional legal conflict", the Romanian Constitutional Court underlined that in its contents it may also enter legal situations of a conflict nature arising directly from the fundamental text of the document. In this respect, by Decision no. 901 of 17 June 2009, the constitutional contentious court established that the concept of constitutional legal conflict "is not confined only to conflicts of positive or negative competence, which could create institutional blockages, but concerns any conflicting legal situations whose birth lies directly in the Constitution". On the contrary, from the case-law of the Court, it results that the conflicts between a political party or a parliamentary group and a public authority does not fall into this category; opinions, value judgments or statements do not constitute by themselves a conflict of this nature; views or proposals regarding the exercise of the competence, even critical, do not trigger institutional blockages, if they are not followed by actions or inactions to hinder the fulfilment of constitutional duties, remaining within the limits of freedom of expression.

Romanian constitutional text envisages three conditions that must be fulfilled in order for the Constitutional Court to intervene to resolve a conflict: a. the conflict must be legal, excluding other types of conflicts: political, social, trade union, etc.; b. the conflict must be of a constitutional nature, targeting only those powers conferred to public authorities through the fundamental act; c. the conflict must be between public authorities, i.e. between those authorities falling under Title III of the Constitution of Romania - Parliament, the President of Romania, the Government, public administration and judicial authority - being excluded from this category the public powers, trade unions, employers, political parties or associations, whatever they may $\mathrm{be}^{2}$.

\section{RESOLUTION PROCEDURE OF THE CONSTITUTIONAL LEGAL CONFLICTS BETWEEN PUBLIC AUTHORITIES}

The competence to solve disputes of a constitutional nature belongs, as we have already mentioned, only to the Constitutional Court, under Article 146 (e) of the Constitution, which is supplemented by the provisions of Articles 34-36 of Law no. 47/1992 on the organization and functioning of the Constitutional Court.

Referral to the Constitutional Court may come from the President of Romania, one of the presidents of the two Chambers, the Prime Minister or President of the Superior Council of Magistracy, without the need for the author's referral to be "party to the conflict".

The request must specify the public authorities in conflict, the legal texts upon which the conflict is bearing, a presentation of the position of the parties and the opinion of the request's author.

\footnotetext{
${ }^{2}$ ȘtefanDeaconu, Legal Disputes of Constitutional Nature between the Juridical Authority and Other Public Authorities in the Case-Law of the Constitutional Court of Romania, AnaleleUniversitățiidin București, seriaDrept, 2011, pp.232-233.
} 
After the president of the Constitutional Court receives the request, he shall notify it to the parties in conflict and urge them to express, in writing, within a deadline, their point of view on the content of the conflict and possible ways to overcome it. He shall also appoint a JudgeRapporteur.

According to Article 35 paragraph (2) of Law no. 47/1992, on receipt of the last standpoint, but not later than 20 days after receiving the request, the President of the Court sets a term for the hearing and summons the parties under conflict. From this legal provision, it can be noticed that the request's author is not quoted to proceedings.

The debate takes place at the date fixed by the President of the Court, in closed session, and even if any of the concerned public authorities do not respect the deadline for submission of its viewpoint. The debate is based on the report of the Judge-Rapporteur, the referral, the points of view presented, the evidence and submissions of the parties.

The resolution of legal conflicts of a constitutional nature between public authorities is made by the Constitutional Court, by decisions. These decisions shall be published in the Official Gazette and are binding from the date of publication, having power only for the future.

The big problem raised by this type of decisions is the fact that they are not exclusively legal. An important political charge is added to their legal side, which is why, in exercising its power, the Constitutional Court must give proof of greater demands on the independence and moral status of judges ${ }^{3}$.

We should also mention the fact that the solutions passed by the Constitutional Court in the matter shall be liable to execution, i.e. to be able to remedy the legal effects produced by the constitutional legal conflict, which intervened between public authorities. The legal failure of enforcement of the solution adopted by the Court equals with the failure to remedy the legal effects and, therefore, with the ineffectiveness of noticing a conflict of competences between public authorities ${ }^{4}$.

\section{THE ROMANIAN PRESIDENT IN LEGAL CONFLICTS OF A CONSTITUTIONAL NATURE}

So far, of the 26 referrals to the Constitutional Court of Romania regarding the settlement of legal disputes of a constitutional nature between public authorities, in 14 cases the President of Romania was involved. Of these, only in five cases the Constitutional Court established that there was a constitutional legal conflict between the President of Romania and another public authority, and in other 9 cases the Court has established that there was not such a conflict.

In the following, we shall analyze the most relevant decisions taken in this matter by the Romanian Constitutional Court, which involved the Romanian head of state and had a major impact on the constitutional relations between the public authorities mentioned in Title III of the Romanian fundamental law.

\section{a. Freedom of the President of Romania to express political opinions}

The first two referrals to the Constitutional Court of the existence of a legal dispute of a constitutional nature between public authorities have focused on the limits of the right to freedom of expression of a person who holds a public office, namely the President of Romania.

\footnotetext{
${ }^{3}$ Ioan Vida, Curtea Constituțională a României: Justiția politicului sau politica justiției?, Monitorul Oficial PublishingHouse, Bucharest, 2000, pp.100-101.

${ }^{4}$ George LiviuGîrleșteanu, Conflictelejuridice de naturăconstituționalădintreautorităţilepublice, RevistaTransilvană de Științe administrative 1/(30), 2012, pp.42-43.
} 
In the first case, the presidents of the two Chambers of the Parliament have asked the Constitutional Court to declare the existence of a legal conflict of a constitutional nature between the President of Romania and Parliament, as consequence of statements made by the Romanian President, TraianBăsescu, concerning the Parliament and political parties, in an interview given to a newspaper of general circulation.

President's remarks, which, among other things, argued that a political party represents "an immoral solution" and instigated to the onset of parliamentary procedure to change the two Presidents of the Chambers of the Parliament and to convene early parliamentary elections, were considered, by the authors of the referral, as being contrary to the specific duties of the President granted by the Constitution.

The second case also has its starting point in the injurious statements of the President of Romania made, this time, to the address of justice and magistrates, generally, referring to the "incompetence", "independence of law" and "high level corruption" from the judiciary system.

Starting from these considerations, the President asked the Superior Council of Magistrates to establish the existence of a constitutional legal conflict between the judicial authority, on the one hand and the Romanian President and Prime Minister, on the other hand.

In both cases, by decision - respectively Decision no. 53 of 28 January 2005 and Decision no. 435 of 26 May 2006 - the Constitutional Court of Romania has established that the declarations of the President, which, otherwise, did not produce any kind of legal effect, did not raise a legal conflict of a constitutional nature between the concerned authorities.

In its reasoning, the Constitutional Court held, in both cases, that the opinions, value judgments and statements of a warrant holder of public office, relating to other public authorities, do not constitute by themselves legal disputes between public authorities. The views or proposals on how it acts or should act a certain public authority or its structures, even being critical, do not trigger institutional blockages if they are not followed by actions or inactions to hinder the fulfilment of constitutional powers of other public authorities. Such opinions or proposals remain within the limits of freedom of political expression, with the restrictions provided for by Article 30 paragraphs (6) and (7) of the Constitution.

Moreover, the Constitutional Court emphasized that, in the activity of fulfilling the constitutional mandates, the public authorities, by the positions they express, are required to avoid creating conflict situations between powers. The constitutional status of the President, as well as his role in the constitutional democracy, compels him to choose the appropriate forms of expression, so that the criticisms he makes against some state powers should not turn into elements that could generate legal disputes of a constitutional nature between them.

\section{b. Romanian President's attribution to dismiss and appoint some members of the Government at the proposal of the Prime Minister}

By decisions no. 356 of 5 April 2007 and no. 98 of 22 February 2008, the Constitutional Court settled the legal disputes of a constitutional nature issued between the President of Romania and the Government of Romania, due to the President's refusal to appoint as minister the persons nominated by the Prime Minister, in the situation of some governmental reshuffle, according to Article 85 paragraph (2) of the Constitution.

This time, the Constitutional Court found the existence of a constitutional legal conflict between the two public authorities, the President of Romania and the Romanian Government, under Article 146 (e) of the Constitution, holding that their disagreement is irreducible and may create an inadmissible institutional blockage capable to impede the proper functioning of Government.

Moving on to the conflict resolution, the Court found that, in fulfilling the duty provided for in Article 65 paragraph (2) of the Constitution, "the President shall dismiss and appoint, on the Prime Minister's proposal, some members of the Government", the President does not enforce a decision of Parliament, but he is in the situation of deciding himself the appointment 
of some ministers on the Prime Minister's proposal. At this stage, the decisional act of the President is by definition an act of will and, therefore, he is free to receive the Prime Minister's proposal or to ask him to make another proposal. However, the Constitutional Court does not recognize to the President an absolute right of veto in this area, excluding the validity of an unjustified, arbitrary refusal (Decision no. 356 of 5 April 2007).

To eliminate the institutional blockage, which would generate through an eventual repeated refusal of the President to appoint a minister on the Prime Minister's proposal, the Constitutional Court turned, more or less forced, to a solution, which in its opinion has the value of a constitutional principle, in resolving legal conflicts between public authorities. More specifically, the Court referred to the constitutional regulation of the law-making process, which provides for the right of the President to ask Parliament to review a law before its promulgation, only once.

Under this principle, in this case, the Court found that, just as in the legislative procedure situation, in exercising the power envisaged by Article 85 paragraph (2) of the Constitution, the President of Romania, without having a right of veto, may ask the Prime Minister once, motivated, to make a new proposal for the appointment of another person as Minister. The Romanian President's reasons for the request cannot be censored by the Prime Minister, who, under the procedure of Article 85 paragraph (2) of the Constitution, has only right to propose to the President to appoint a minister and he does not enjoy decisional competency. As with the exercise of other powers provided for by the Constitution, the President remains politically responsible to the electorate for how he motivated the refusal to follow the proposal of the Prime Minister, as the Prime Minister and the Government remain politically responsible to Parliament (Decision no. 98 of 7 February 2008).

Another aspect related to the Romanian President's duty of appointing new members of the Government was brought to the attention of Romanian constitutional judges at the constitutional legal conflict resolution between the Romanian Parliament and Romanian President by Decision no. 1560 of 18 November 2009. In essence, the referral of the Senate's President invoked the impossibility of the President of Romania to appoint an interim minister without the approval of Parliament [according to Article 85 paragraph (3) of the Constitution], given that through this appointment the political structure or composition of the Government was changed.

Holding that there is no conflict between the two authorities, by Decision no. 1560/2009, the Constitutional Court stressed the inapplicability of the provisions of Article 85 paragraph (3) of the Constitution in the case of the appointment of interim ministers, unlike the case of appointment of new members of the Government. Thus, the Court has noted: "the appointment of ministers in case of government reshuffle is a distinct constitutional institution with a constitutional regulation distinct from that designation of interim ministers. Since the appointment of interim ministers, governed by article 107, paragraph (4) of the Constitution does not require the exercise of Parliament as referred to Article 85 paragraph (3) of the Fundamental Law, it cannot be supposed the violation in this matter by the President of Romania of this power, or of "preliminary procedure" imposed by the same constitutional text". Only this conclusion may be accepted from both the literal interpretation of constitutional texts of reference (Article 85 of the Constitution which refers to the appointment of the Government, while article 107 paragraphs (3) and (4) of the Constitution refers to the appointment of other members of the Government as interim ministers) and from a systematic interpretation of the constitutional provisions contained in Article 85 (Appointment of the Government), Article 103 (Investiture), Article 104 (Oath of allegiance ) Article 106 (Cessation of membership of the Government), Article 107 (Prime Minister). 


\section{c. The duty of representing the Romanian state at the European Council}

Another conflict that reached the Romanian constitutional judges' table referred to the Romanian state representation in European forums, namely, the European Council. Thus, the President brought before the Constitutional Court the conflict between the Government, represented by the Prime Minister, on the one hand, and the President of Romania, on the other hand, conflict generated by the action of the Government and Prime Minister to exclude the President of Romania from the delegation attending the European Council and, consequently, the assumption by the Prime Minister of the constitutional duty to represent the Romanian state at the European Council.

By Decision no. 683 of 27 June 2012, the Constitutional Court declared admissible the complaint made by the President of Romania, noting the existence of a legal conflict of a constitutional nature between the Government and the President of Romania, due to the following reasons:

- public positions of the representatives of the two authorities have given rise to tensions that meet the constituent elements of the concept of conflict;

- the conflict is a legal one, as it aims to determine the role that the President and the Government have in defining and orientation of the State's foreign policy;

- the legal conflict is of a constitutional nature, as it aims the interpretation of Article 80 paragraph (1) and Article 102 paragraph (1) of the Constitution, which regulate the role of the President of Romania and the Government in achieving the country's foreign policy.

On the merits of the case, in solving the constitutional conflict, the Constitutional Court decided that the representation of the Romanian State at the highest level belongs to the President of Romania.

In order to decide thus, the provisions of Article 80 paragraph (1) of the Constitution were taken into consideration, "the President of Romania shall represent the Romanian State", which were interpreted in the sense that the Head of State is the person leading and engaging the State's foreign policy. This constitutional text allows the President to draw future lines that the State shall follow in its foreign policy. Basically, it shall determine its orientation in external relations, taking into account, of course, the national interest. Such a conception is legitimate by the representative character of the office, the Romanian President being elected by the citizens by universal, equal, direct and secret suffrage. On the contrary, the Government's role in foreign policy is rather of a technical nature, it must follow and meet the obligations to which Romania has undertaken at State level. Thus, the role of Government is diverted and not original, as the one of the President of Romania. Fulfilling one of his powers when representing the Romanian State, the Romanian President may also delegate this power to the Prime Minister, by an act of will, when he considers this to be necessary (Decision no. 683 of 27 June 2012).

\section{d. Powers to grant the military rank of general}

At the request of the President, the Constitutional Court was asked to rule on the existence of a legal conflict of constitutional nature between the President of Romania, on the one hand, and the judicial authority, represented by the High Court of Cassation and Justice, on the other hand, conflict raised because the Supreme Court failed to comply with a decision given by the Constitutional Court. This conduct of the High Court of Cassation and Justice put the Romanian President in the impossibility to respect the same time both the decision of the court and that of the Constitutional Court.

More specifically, by Decision no. 384 of 4 May 2006, the Constitutional Court ruled that the provisions of Article 66 paragraph (3) of Law no. 80/1995 on statute of military staff, according to which "Colonels and Commanders in activity, with a length in rank of at least 5 years and have been employed for at least 3 years in offices provided in the organisational charts with the rank of general or similar, assessed in this period with a grade of very good, upon discharge or directly upon retirement will be awarded with the rank of Brigadier 
General, respectively of general of aviation fleet or admiral of fleet, and will be discharged or directly retired with the new rank" are unconstitutional, contrary to the provisions of article 94 letter (b) of the Constitution.

By Decision no. 384/2006, mentioned above, the Constitutional Court ruled that the duty of the President of Romania, exercised in his capacity as head of state and commander of the armed forces, to grant degrees of marshal, general and admiral represents one of his rights and not an obligation. In this regard, the Court held that "the President has the opportunity to determine whether or not to grant these degrees without being conditioned by law, as appropriate to the duty of appointments to public offices. The Court finds that the criticized text of the law provides in an imperative form the advancement in rank of colonels and commanders in activity upon discharge or directly upon retirement, if they comply with the conditions of seniority in rank and grade required by law. The duty of the President of Romania provided for in Article 94 letter b) of the Constitution appears, in this case, as a formal intervention to fulfill certain legal provisions. Thus, this authority is deprived of the very substance of the constitutional powers".

Later, contrary and totally ignoring the decision of the Constitutional Court, the High Court of Cassation and Justice established by a one of its decisions, under Article 66 paragraph (3) of Law no. 80/1995 on statute of military staff, the right of a complainant to be promoted by the President of the State to the rank of general.

Consequently, in view of the above, the Constitutional Court, by Decision no. 1222 of 12 November 2008, found that there was a constitutional legal conflict between the President of Romania, on the one hand, and the High Court of Cassation and Justice, on the other hand, conflict generated because the Supreme Court ignored the Decision no. 384/2006 of the Constitutional Court. It was found that the decision of the Supreme Court was unenforceable against the President, who was not party to proceedings and, extremely important, the Constitutional Court reiterated the exclusive power of the President of Romania to grant the rank of general, under Article 94 letter b) of the Constitution.

\section{CONCLUSION}

The semi-presidential political system enshrined in the Constitution contains many sources of conflict within the executive power or between the executive and legislative, conflicts that fully manifest in certain political contexts, such as, for example, the cohabitation. The main cause of these conflicts is represented, in our opinion, by the ambiguity of the constitutional provisions on the distribution of powers between the President, Government, Parliament and the judiciary power.

Entrusting to the Constitutional Court the power to resolve legal conflicts of a constitutional nature between public authorities is likely to increase the role of this institution among the state authorities. Thus, from the experience until now, it results that the Constitutional Court has a fairly wide margin of appreciation as regards the possibility of interpreting constitutional rules on the powers of public authorities. In some cases, the Constitutional Court even added new interpretation to the constitutional text based on principles borrowed from other institutions, as it happened in the case we have presented in detail in section 3.b. Sometimes, the Constitutional Court, seeking an escalation of conflict settlement, issued a conjectural solution.

We must emphasize, by paraphrasing the European Commission for Democracy through Law (Venice Commission) that the Constitutional Court is not and should not be an organ of mediation between the State's powers in charge of settling their disputes and of finding "political" solutions for their differences. The Constitutional Court must act as a balancing factor in the Romanian society and among the Romanian authorities as a true guarantor of the 
rule and respect of the Constitution. And for this to be done, the Court's judges shall manifest total independence from the authorities or political majorities that have appointed them, high moral integrity and professional competence.

\section{REFERENCES}

1. IoanMuraru, Elena SiminaTănăsescu, ConstituțiaRomâniei. Comentariupearticole, Editura CH Beck, Romania, pp. 1404-1405, 2008.

2. ȘtefanDeaconu, Legal Disputes of a Constitutional Nature between the Judicial Authority and the other Public Authorities in the Case-Law of the Constitutional Court of Romania, AnaleleUniversității din București, seriaDrept, Romania, II, pp. 232-233, 2011.

3. Ioan Vida,

CurteaConstituțională

României. Justițiapoliticuluisaupoliticajustiției?,MonitorulOficial, Romania, pp. 100-101, 2000.

4. George LiviuGîrleșteanu, Conflictelejuridice de naturăconstituționalădintreautorităţilepublice, RevistaTransilvană de Științe Administrative, Romania, 1/(30), pp. 42-43, 2012. 